\title{
Inhibition of Casein kinase-2 induces p53-dependent cell cycle arrest and sensitizes glioblastoma cells to tumor necrosis factor (TNF $\alpha$ )-induced apoptosis through SIRT1 inhibition
}

\author{
D Dixit ${ }^{1}$, V Sharma ${ }^{1}$, S Ghosh ${ }^{1}$, VS Mehta ${ }^{1,2}$ and E Sen ${ }^{\star, 1}$
}

Glioblastoma multiforme (GBM) are resistant to TNF $\alpha$-induced apoptosis and blockade of TNF $\alpha$-induced NF- $\kappa$ B activation sensitizes glioma cells to apoptosis. As Casein kinase-2 (CK2) induces aberrant NF- $\kappa$ B activation and as we observed elevated CK2 levels in GBM tumors, we investigated the potential of CK2 inhibitors (CK2-Is) - DRB and Apigenin in sensitizing glioma cells to TNF $\alpha$-induced apoptosis. CK2-Is and CK2 small interfering RNA (siRNA) reduced glioma cell viability, inhibited TNF $\alpha$-mediated NF- $\kappa$ B activation, and sensitized cell to TNF $\alpha$-induced apoptosis. Importantly, CK2-Is activated p53 function in wild-type but not in p53 mutant cells. Activation of p53 function involved its increased transcriptional activation, DNA-binding ability, increased expression of p53 target genes associated with cell cycle progression and apoptosis. Moreover, CK2-Is decreased telomerase activity and increased senescence in a p53-dependent manner. Apoptotic gene profiling indicated that CK2-Is differentially affect p53 and TNF $\alpha$ targets in p53 wild-type and mutant glioma cells. CK2-I decreased MDM2-p53 association and p53 ubiquitination to enhance p53 levels. Interestingly, CK2-Is downregulated SIRT1 activity and over-expression of SIRT1 decreased p53 transcriptional activity and rescued cells from CK2-I-induced apoptosis. This ability of CK2-Is to sensitize glioma to TNF $\alpha$-induced death via multiple mechanisms involving abrogation of NF- $\kappa$ B activation, reactivation of wild-type p53 function and SIRT1 inhibition warrants investigation.

Cell Death and Disease (2012) 3, e271; doi:10.1038/cddis.2012.10; published online 9 February 2012

Subject Category: Cancer

Despite its ability to induce apoptosis, several tumors are resistant to TNF $\alpha$-mediated apoptosis. ${ }^{1}$ This resistance has been attributed to TNF $\alpha$-mediated NF- $\kappa \mathrm{B}$ activation as blockade of $\mathrm{NF}-\kappa \mathrm{B}$ sensitizes cells to $\mathrm{TNF} \alpha$-induced cell death. $^{2,3}$ Some anti-cancer chemotherapeutic drugs in combination with $\mathrm{TNF}_{\alpha}$ can kill resistant tumor cells. ${ }^{4}$ Glioblastoma multiforme (GBM) - the most aggressive malignant brain tumor, is largely resistant to current therapeutic regimens. We have reported that organoselenium Ebselen sensitizes glioma cells to TNF $\alpha$-induced apoptosis by abrogating NF- $\kappa$ B activation. ${ }^{5}$

Casein kinase-2 (CK2) - a protein kinase important for cell survival and resistance to apoptosis, ${ }^{6}$ is over-expressed in several malignancies. ${ }^{7}$ CK2 negatively regulates caspase activity ${ }^{8}$ and CK2 inhibitors (CK2-Is) increase the susceptibility of cancer cells to chemotherapeutic agents or apoptotic stimuli. ${ }^{9}$ CK2 inhibitor, DRB, sensitizes tumor cells to TRAIL (TNF $\alpha$ related apoptosis inducing ligand)-induced apoptosis. ${ }^{10} \mathrm{CK} 2$ inhibitor, Apigenin, inhibits NF- $\kappa$ B activation in breast cancer cell lines ${ }^{11}$ and DRB enhances Apo2L/TRAIL-induced glioma cell death. ${ }^{12}$ CK2-I blocks TNF $\alpha$-induced p 65 phosphorylation ${ }^{13}$ and reduces constitutive NF- $\kappa \mathrm{B}$ activity in breast cancer cells. ${ }^{14}$
TNF $\alpha$-activated NF- $\kappa$ B represses $p 53$ transcriptional activity and vice versa. ${ }^{15}$ Most GBMs harbor p53 mutations, which are considered critical in GBM development ${ }^{16}$ and p53 rescue compounds induce p53-dependent growth arrest and sensitizes glioma cells to Apo2L/TRAIL-induced apoptosis. ${ }^{17}$

SIRT1 an NAD+ (nicotinamide adenine dinucleotide)dependent deacetylase, known to decrease transcriptional activity of $\mathrm{p} 53,{ }^{18}$ is a component of CK2-regulated anti-apoptotic network. ${ }^{19}$ Silencing of SIRT1 enhances sensitivity of glioblastoma to radiotherapy. ${ }^{20}$ Accordingly, we investigated whether CK2-Is could sensitize glioma cells to TNF $\alpha$-induced apoptosis through regulation of molecules associated with cell survival and resistance to apoptosis such as NF- $\kappa \mathrm{B}, \mathrm{p} 53$ and SIRT1.

\section{Results}

Elevated CK2 levels in glioblastoma biopsy samples. Though the ability of CK2 inhibitor to regulate DNA damage repair response and induce antitumor activity in a mouse xenograft model of human glioblastoma has been reported, ${ }^{21}$ nothing is known about the status of CK2 in human glioma samples. We therefore investigated the status

${ }^{1}$ National Brain Research Centre, Manesar, Gurgaon, Haryana 122050, India and ${ }^{2}$ Paras Hospitals, Gurgaon, Haryana 122050, India

${ }^{*}$ Corresponding author: E Sen, National Brain Research Centre, Manesar, Gurgaon, Haryana 122050, India. Tel: + 91124 2338921, Extn: 235; Fax: + 91 124 2338910/28; E-mail: ellora@nbrc.res.in

Keywords: glioblastoma; casein kinase-2; TNF $\alpha$; NF- $\kappa$ B; p53

Abbreviations: CK2-I, casein kinase-2 inhibitor; NF- $\kappa$ B, nuclear factor kappa B; SIRT1, sirtuin 1; TNF $\alpha$, tumor necrosis factor alpha; GBM, glioblastoma multiforme; DRB, 5,6-dichlorobenzimidazole 1- $\beta$-D-ribofuranoside; CK2a/b siRNA, siRNA against a and $b$ subunits of casein kinase-2; FADD, Fas-associated protein with death domain; $1 \kappa \mathrm{K}$, inhibitor of nuclear factor kappa B kinase; MDM2, murine double minute; NS siRNA, non-specific siRNA

Received 09.11.11; revised 15.12.11; accepted 12.1.12; Edited by A Verkhratsky 
of CK2 in GBM tumors. Immunohistochemistry (IHC) revealed an elevated expression of $\mathrm{CK} 2 \alpha$ in GBM tumors as compared with adjacent normal tissues (Figure 1a).
Western blot analysis also confirmed an increased CK2 $\alpha$ expression in glioma tissue as compared with the surrounding non-neoplastic tissue (Figure 1b).
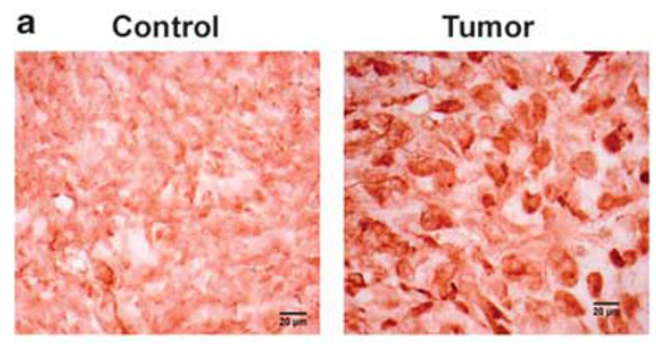

b
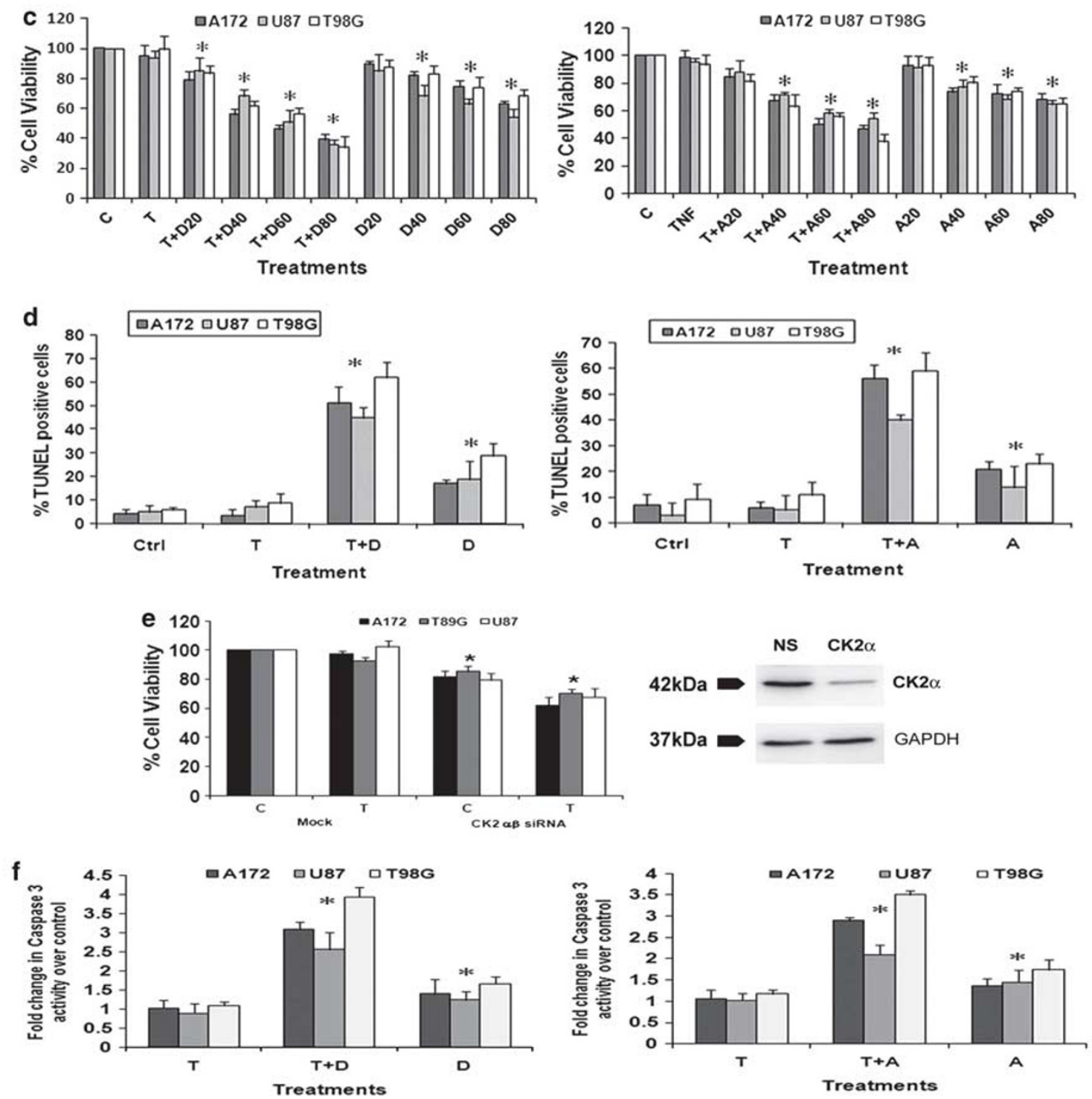

Figure 1 CK2 inhibition sensitizes glioma cells to TNF $\alpha$-induced apoptosis. (a) CK2 immuno-localization in glioma tumor samples. Cryosections of glioma and adjacent normal tissues were immunostained for CK2 $\alpha$ as described in Materials and Methods. Images were taken at $40 \times$ magnification. (b) Western blot analysis demonstrating elevated CK2 $\alpha$ expression in GBM tumor as compared with surrounding non-neoplastic tissue. The figure shows blots from five independent tumor samples with identical results. (c) Viability of glioma cells treated with CK2-Is in the presence and absence of TNF $\alpha$ was determined by MTS assay. The graphs represent the viable glioma cells, percentage of control, upon treatment with $50 \mathrm{ng} / \mathrm{ml}$ TNF $\alpha$ either alone or in combination with different concentrations of DRB or Apigenin for $24 \mathrm{~h}$. (d) The graphs represent percentage of TUNEL-positive glioma cells upon treatment with either DRB/Api or TNF $\alpha$ or both, as counted from multiple fields. (e) siRNA-mediated knockdown of CK2 decreases glioma cell viability as determined by MTS assay. The graph represents the viable glioma cells, percentage of control, transfected with CK2 $\alpha / \beta$ siRNA when treated with TNF $\alpha$ for $24 \mathrm{~h}$. Inset shows the knockdown efficiency of CK2 $\alpha$ siRNA. (f) Increase in caspase-3 activity in glioma cells treated with CK2-Is or TNF $\alpha$ or both, as determined by caspase-3 activity assay. Values $(\mathbf{c}-\mathbf{f})$ represent the means \pm S.E.M. from three independent experiments. ${ }^{*}$ Denotes significant change from control $(P<0.05)$ 
CK2 regulates glioma cell viability and confers resistance to TNF $\alpha$-induced apoptosis. As CK2 levels were elevated in GBM samples, we investigated its role in glioma cell survival and resistance to apoptosis. Although treatment with $20 \mu \mathrm{M}$ of DRB had no effect on cell viability, $\sim 20-30 \%$ reduction in viability was observed upon treatment with 40,60 and $80 \mu \mathrm{M}$ of $\mathrm{DRB}$, respectively (Figure 1c). Although treatment with $\mathrm{TNF} \alpha$ alone had no effect on viability of glioma cells, co-treatment with 20, 40, 60 and $80 \mu \mathrm{M}$ of DRB resulted in $\sim 30-65 \%$ decrease in viability, as compared with control (Figure 1c). Similarly, Apigenin also affected cell viability (Figure 1c). Thus, both DRB and Apigenin sensitized glioma cells to TNF $\alpha$-induced apoptosis. We chose $40 \mu \mathrm{M}$ concentration of DRB and Apigenin for subsequent treatments. To further confirm CK2-I-mediated apoptotic death, TUNEL assay was performed (Figure 1d). The 15-25\% increase in TUNELpositive cells observed upon DRB and Apigenin treatment was further elevated to $\sim 50-60 \%$ when DRB or Apigenin was co-administered with TNF $\alpha$ (Figure 1d). To further confirm the involvement of CK2 in glioma cell survival, viability of cells transfected with small interfering RNAs (siRNAs) against $\alpha$ and $\beta$ subunit of CK2, both in presence and absence of TNF $\alpha$ was determined. The $20-25 \%$ decrease in cell viability observed upon siRNA-mediated knock-down of CK2 $\alpha / \beta$ subunits was further elevated to $30-40 \%$ in the presence of TNF $\alpha$ (Figure 1e).

The significant 1.3, 1.5 and 1.7-fold increase in caspase-3 activity observed in U87MG, A172 and T98G cells upon treatment with DRB, respectively, was further elevated to 2.9, 3.2 and 4.0 -fold in the presence of TNF $\alpha$. Similar activation of caspase- 3 was also observed in cells treated with Apigenin either alone or in combination with TNF $\alpha$ (Figure 1f).

CK2-I-mediated apoptosis does not involve caspase-8 activation. Interaction of Fas with FADD recruits procaspase- 8 that induces subsequent caspase- 8 and caspase-3 activation leading to apoptosis. Although CK2 inhibition is known to trigger apoptosis through FADD and caspase-8, ${ }^{22}$ CK2-Is had no effect on FAS or FADD expression (Figure $2 a$ ) or caspase-8 activity (Figure $2 b$ ) in glioma cells, both in presence and absence of $\operatorname{TNF} \alpha$. To further confirm the role of caspase-8, the viability of cells treated with different combinations of TNF $\alpha$ and CK2-I in the presence and absence of caspase- 8 inhibitor was determined. CK2-I-mediated decrease in cell viability remained unaffected in the presence of caspase- 8 inhibitor (Figure 2c). This ruled out the possible involvement of caspase-8 in CK2-I-induced apoptosis.

CK2-Is abrogate TNF $\alpha$ induced NF- $\kappa$ B activity in glioma cells. CK2 is known to regulate NF- $\kappa \mathrm{B}$ through regulation of IKK. ${ }^{23}$ Treatment with CK2 inhibitors decreased TNF $\alpha$ induced $\mathrm{pl} \kappa \mathrm{K} \alpha / \beta$ level in glioma cells (Figure $2 \mathrm{~d}$ ). This decrease was concomitant with increase in $\mathrm{I}_{\kappa} \mathrm{B} \alpha$ and decrease in NF- $\kappa \mathrm{B}$ levels (Figure $2 \mathrm{~d}$ ). As CK2-I prevents $\mathrm{NF}-\kappa \mathrm{B}$ activation, ${ }^{11}$ we investigated whether $\mathrm{CK} 2$-Is increase sensitivity to TNF $\alpha$-induced apoptosis through inhibition of $\mathrm{NF}-\kappa \mathrm{B}$ activity. Transfection of glioma cells with NF- $\kappa \mathrm{B}$ luciferase reporter followed by $\mathrm{TNF} \alpha$ treatment demonstrated 9-11-fold increase in luciferase activity over the vector control (Figure 2e). Although treatment with DRB or Apigenin alone had no significant effect on NF- $\kappa$ B activity, CK2-Is reduced TNF-induced NF- $\kappa$ B activity to levels comparable to control (Figure 2d). Similar decrease in TNF $\alpha$-induced NF- $\kappa \mathrm{B}$ luciferase activity was observed in cells transfected with CK2 $\alpha / \beta$ siRNAs (Figure 2f), confirming the involvement of $\mathrm{CK} 2$ in TNF $\alpha$-induced aberrant NF- $\kappa$ B activation.

CK2-Is increases p53 expression in glioma cells. As TNF $\alpha$-activated NF- $\kappa$ B represses p53 transcriptional activity and vice versa, ${ }^{15}$ and as CK2-Is decreased TNF $\alpha$-induced $\mathrm{NF}-\kappa \mathrm{B}$ activation, we determined p53 status in CK2-I- and TNF $\alpha$-treated cells. A dramatic increase in p53 levels accompanied with an increase in phosphorylation (Ser-15) and acetylation (Lys373, 382) of p53 was observed upon treatment with CK2-Is either alone or in the presence of $\mathrm{TNF} \alpha$ (Figure 3a). This increase was greater in p53 wild-type (U87MG and A172) cells as compared with the slight increase observed in p53 mutant (T98G) cells. Though A172 is known to be a p53 mutant cell line, ${ }^{24}$ sequencing of DNA-binding region of p53 suggested it to be p53 wild type for DNA-binding domain. p53 status in the glioma cell lines was confirmed by sequencing (Supplementary Table 1).

CK2 inhibition increases DNA-binding ability and transcriptional activity of wild-type p53. Further, we went on to investigate the effect of CK2-I-mediated increase in p53 phosphorylation and acetylation on its functional activity. Although CK2-Is increased DNA-binding ability of p53 in U87MG and A172 by 2-4-fold either alone or in combination with TNF $\alpha$, it had no significant effect on the binding ability of mutant p53 in T98G cells (Figure 3b). This suggested that CK2 inhibition restores the function of wild-type p53 independent of TNF $\alpha$. Similarly, although a 2-3-fold increase in p53 transcriptional activity was observed in CK2-I-treated U87MG and A172 cells, its activity remained unaltered in T98G cells (Figure $3 \mathrm{c}$ ). This CK2-I-induced increase in p53 DNA-binding ability and transcriptional activity in U87MG and A172 cells was significantly reduced in the presence of p53 inhibitor, Pifithrin- $\alpha$ (Figures $3 b$ and $c$ ). The relevance of CK2 in the activation of p53 function was further confirmed in U87MG and A172 cells, where siRNA-mediated knockdown of CK2 $\alpha / \beta$ increased p53 transcriptional activity (Figure 3d).

CK2-I-mediated increased p53 activity reduces glioma cells viability. To establish the functional significance of this increased p53 levels, we determined the viability of CK2-Itreated glioma cells in the presence of $\operatorname{TNF} \alpha$, p53 inhibitor Pifithrin- $\alpha$ or both. The $50 \%$ decrease in cell viability observed in U87MG and A172 upon treatment with TNF $\alpha$ and DRB was significantly reduced to $\sim 25 \%$ when TNF $\alpha$ and CK2-I treatment was supplemented with Pifithrin- $\alpha$ (Figure $3 e$ ). Similar results were obtained with Apigenin also. This ability of Pifithrin- $\alpha$ to reverse TNF $\alpha$ and CK2-Imediated decrease in cell viability indicated the involvement of p53 in CK2-I-induced cell death in p53 wild-type glioma cells. However, ability of Pifithrin- $\alpha$ to reverse TNF $\alpha$ - and CK2-I-mediated cell death in p53 mutant T98G cells was not 
a

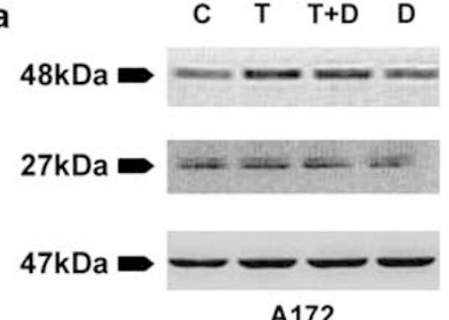

A172
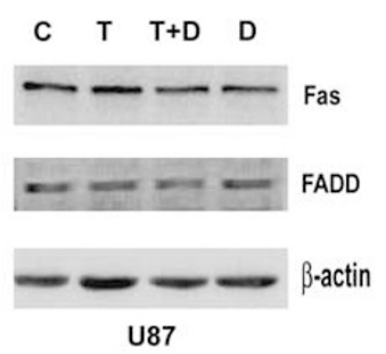

c

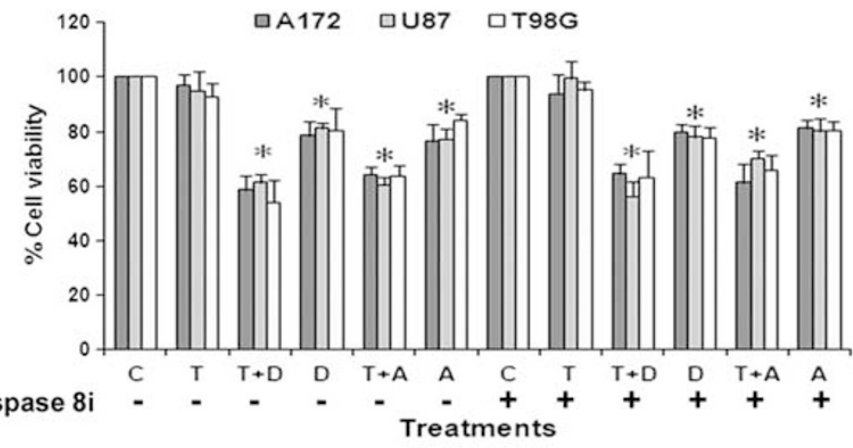

b
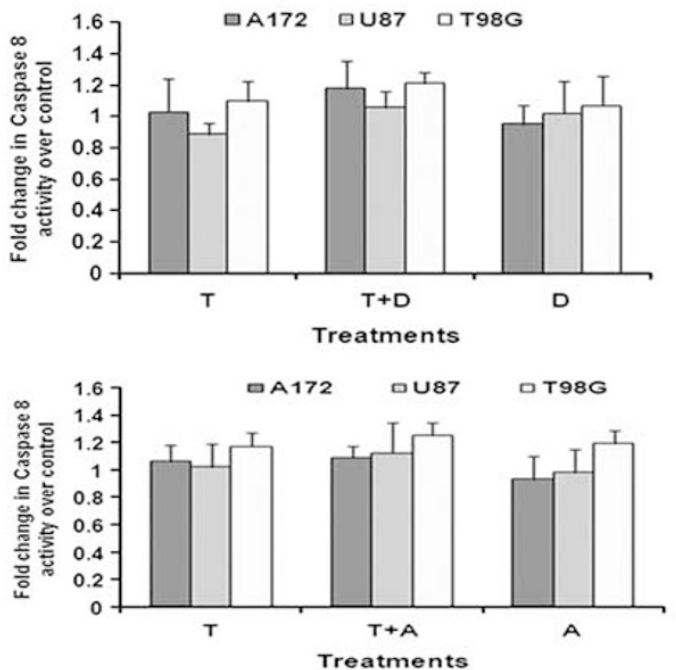

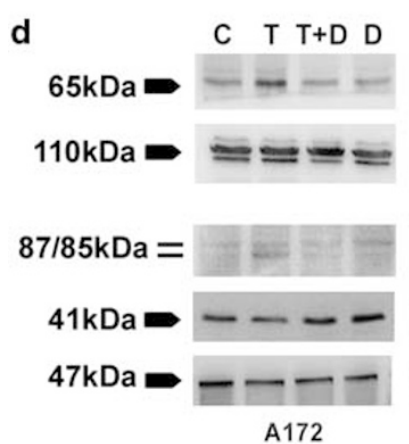

A172
C T T+D D

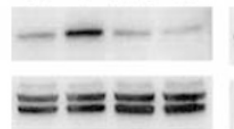

C T T+D D
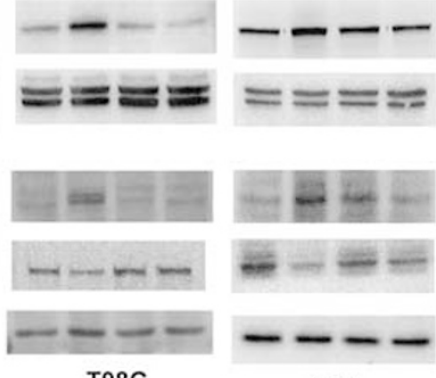

T98G

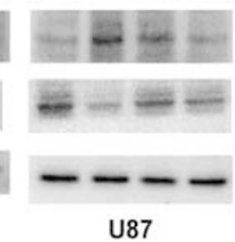

U87

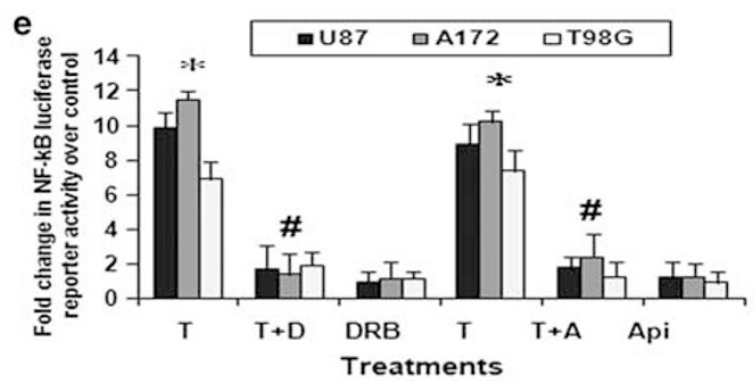

C T T+A A

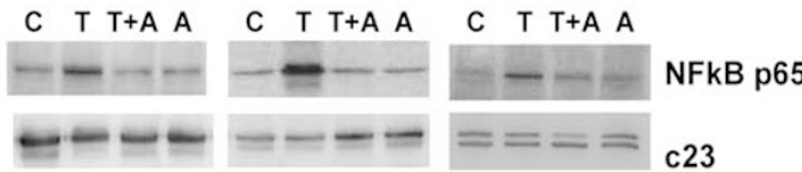

C T T+A A
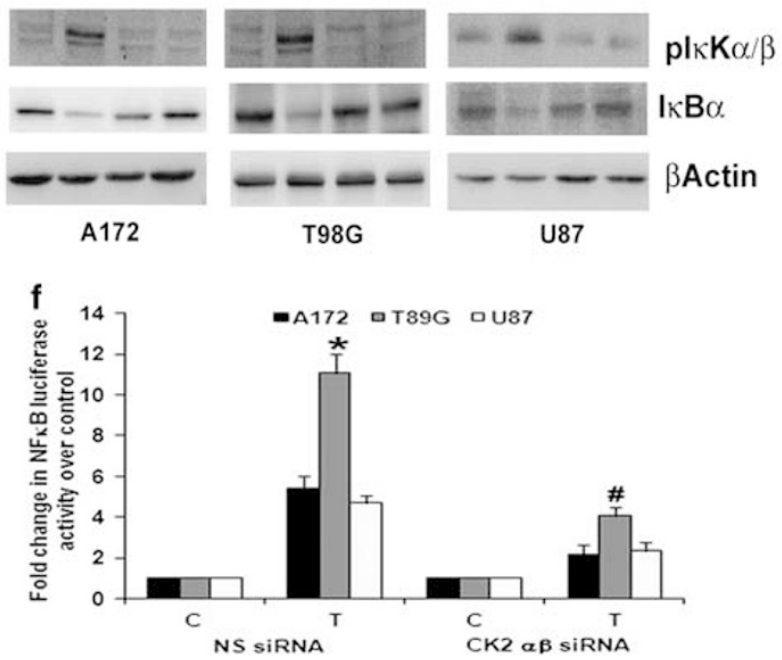

Figure 2 CK2 inhibitors abrogate TNF $\alpha$-induced NF- $\kappa$ B activation. (a) Fas and FADD expression in glioma cells treated with either TNF $\alpha$ or CK2-I or both for $24 \mathrm{~h}$ as demonstrated by western blot. A representative blot is shown from three independent experiments with identical results. Blots were reprobed for $\beta$-actin to establish equivalent loading. (b) Caspase-8 activity in glioma cells treated with CK2-Is or TNF $\alpha$ or both for $24 \mathrm{~h}$, as determined by the caspase-8 activity assay kit. (c) The graph represents the viable cells, percentage of control, observed when glioma cells were treated with different combinations of TNF $\alpha$, CK2-Is and caspase-8 inhibitor, as determined by MTS assay. (d) The levels of NF- $\kappa \mathrm{B}, \mathrm{pl} \kappa \mathrm{K} \alpha / \beta$ and $\mathrm{I}_{\kappa} \mathrm{B} \alpha$ in glioma cells, treated with either TNF $\alpha$ or CK2-Is or both, as demonstrated by western blot. A representative blot is shown from three independent experiments with identical results. Blots were reprobed for $\beta$-actin and c23 to establish equivalent loading. (e) DRB and Apigenin decreases TNF $\alpha$ mediated NF- $\kappa$ B activation in glioma cells. The graph represents fold change in NF- $\kappa$ B luciferase activity over control, in cells treated with TNF $\alpha$ in the presence and absence of CK2-Is. (f) siRNA-mediated knockdown of CK2 $\alpha / \beta$ decreases TNF $\alpha$-induced NF- $\kappa$ B activation in glioma cells. Values in (b, $\mathbf{c}, \mathbf{e}$ and $\mathbf{f}$ ) represent the mean \pm S.E.M. from three independent experiments. *Denotes significant change from control $(P<0.05),{ }^{\#}$ denotes significant change from TNF $\alpha$. T, D and A denote TNF $\alpha$, DRB and Apigenin, respectively

significant (Figure 3e). Similarly, siRNA-mediated p53 knockdown was able to rescue CK2-l-induced cell death both in the presence and absence of TNF $\alpha$ in p53 wild-type glioma cells only (Figure $3 \mathrm{f}$ ). These results confirm the involvement of p53 in CK2-I-mediated glioma cell death. p53 null cells are resistant to CK2-I-induced apoptosis. To confirm the involvement of CK2-I-induced p53 activation in inducing apoptosis, the effect of CK2-I on the viability of p53 null cells $\mathrm{H} 1229$ and SaOS2 was investigated. Both the p53 null cell lines were resistant to 

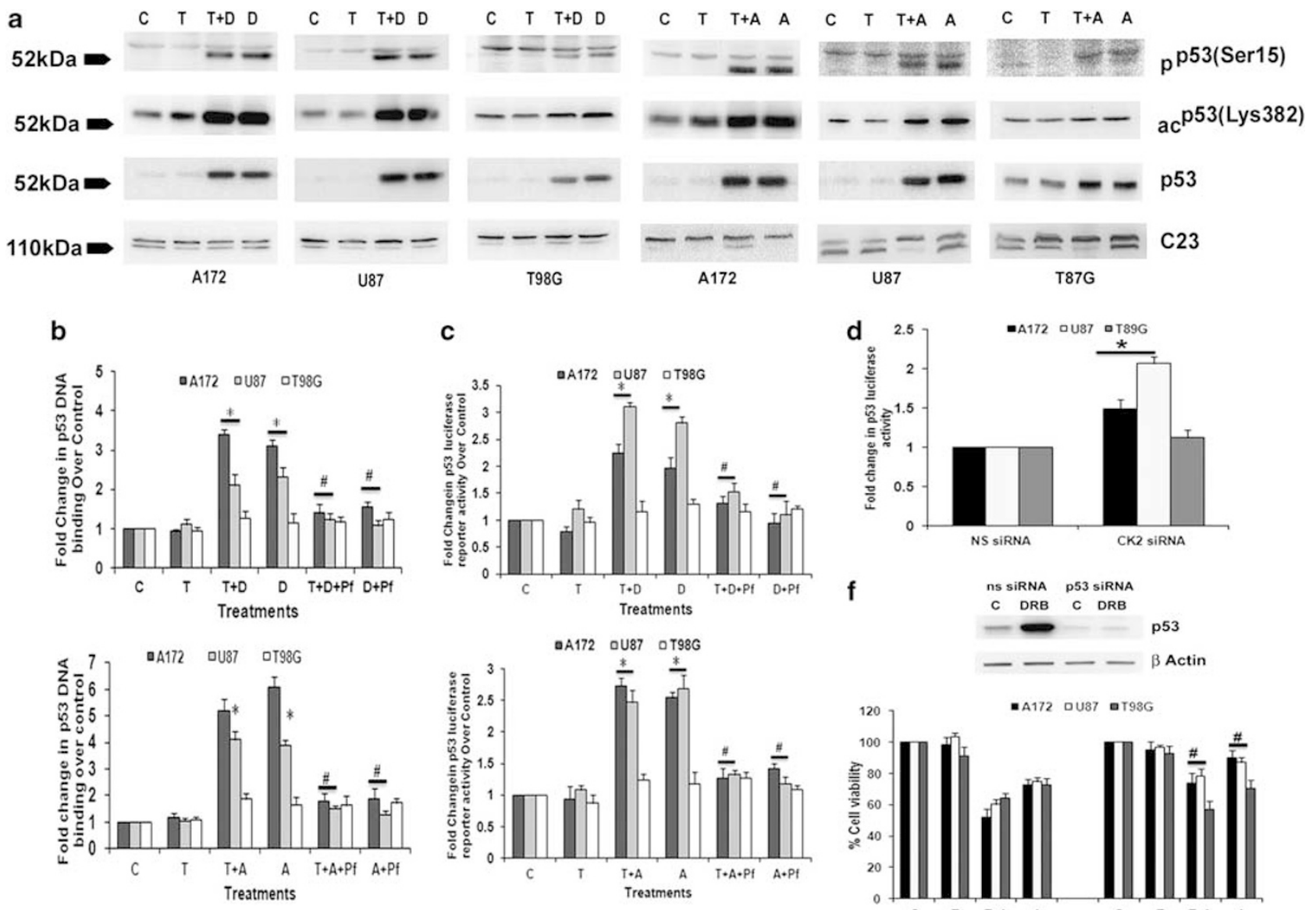

C
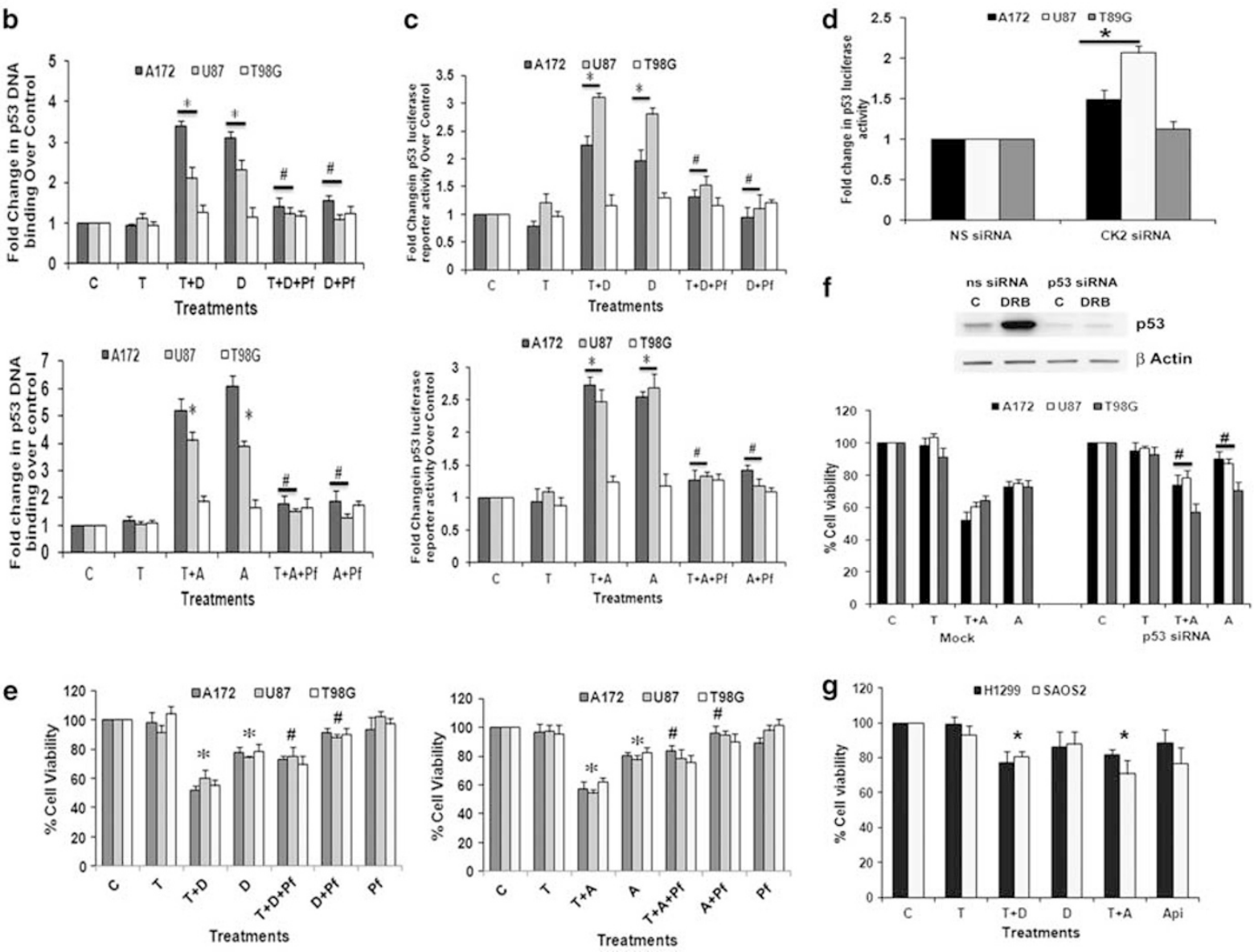

Figure 3 CK2 inhibition triggers p53 expression and activation to induce glioma cell death. (a) Western blot indicated phosphorylated, acetylated and total p53 levels in cells treated with CK2-Is in the presence and absence of TNF $\alpha$. A representative blot is shown from three independent experiments with identical results. c23 was used as loading control. (b) Increased binding of p53 to its DNA-binding sequence in cells treated with CK2-Is, either alone or in combination with TNF $\alpha$, is abrogated by p53 inhibitor, Pifithrin- $\alpha$, The graphs represent relative binding activity of p53 under different conditions, as compared with untreated controls. Values represent means \pm S.E.M. from three individual experiments. (c) CK2-I-mediated increase in p53 transcriptional activity is abrogated upon p53 inhibition. The graphs represent fold change in p53 luciferase reporter activity over control in cells treated with different combinations of CK2-Is, TNF $\alpha$ and Pifithrin- $\alpha$ for $12 \mathrm{~h}$. (d) siRNA-mediated knockdown of CK2 $\alpha / \beta$ induces p53 transcriptional activity in p53 wild-type but not in mutant cell lines. The graph represents fold change in p53 luciferase reporter activity over NS-siRNA-transfected control. (e) CK2-I-mediated sensitization of glioma cells to TNF $\alpha$-induced death is reversed by Pifithrin- $\alpha$ and (f) p53 siRNA. The graphs represent percentage viable glioma cells treated with different combinations of CK2-Is, TNF $\alpha$ and Pifithrin- $\alpha$ for $24 \mathrm{~h}$, as determined by MTS assay. (Inset) p53 siRNA abrogates CK2-I-induced p53 levels as determined by western blot analysis. (g) CK2-I reduced viability of p53 null cells lines only in presence of TNF $\alpha$. The graph represents percentage viable SAOS2 and H1299 cells treated with different combinations of CK2-Is and TNF $\alpha$. Values in $(\mathbf{b}-\mathbf{g})$ represent the means \pm S.E.M. from three independent experiments. *Denotes significant change from untreated control, \#denotes significant change from CK2-I-treated cells either alone or in presence of TNF $\alpha(P<0.05)$

CK2-I-induced apoptosis, as treatment with DRB and Apigenin failed to induce apoptosis in both these cells. However, CK2-I-mediated sensitization of p53 null cells to $\mathrm{TNF} \alpha$ could have resulted from downregulation of NF- $\kappa \mathrm{B}$ activity (Figure $3 \mathrm{~g}$ ).
CK2-Is increase expression of p53 target genes associated with cell cycle regulation and apoptosis. We next investigated whether activation of p53 function induces genes that promote cell cycle arrest (p21and GADD45 $\beta$ ) and apoptosis (Noxa). Although TNF $\alpha$ 
alone had no effect on p21, CK2-ls either alone or in combination with TNF $\alpha$ elevated p21 expression (Figure 4a). CK2-Is either alone or in combination with TNF $\alpha$ increased mRNA levels of p53-induced pro-apoptotic molecules GADD45 $\beta$ and Noxa (Figure 4a). This increase in p21, Noxa and GADD45 $\beta$ level was downregulated by Pifithrin- $\alpha$ (Figures $4 a$ and b). No change in Noxa and GADD $45 \beta$ levels was observed in cells treated with TNF $\alpha$ alone (Figure $4 \mathrm{~b}$ ).

As changes in p21 expression indicated alteration in cell cycle progression, we performed FACS analysis to determine the cell cycle profile of glioma cells treated with different combination of CK2-Is, TNF $\alpha$ and Pifithrin $\alpha$. Although TNF $\alpha$ had no significant effect on cell cycle progression, treatment with CK2-I induced G2/M arrest both in the presence and absence of TNF $\alpha$ (Figure 4b). A 5.4, 5.8, 15.3 and $14.3 \%$, cells at $\mathrm{G} 2 / \mathrm{M}$ phase was observed in control, TNF $\alpha$, Apigenin, TNF $\alpha$ and Apigenin-treated A172 cells, respectively. Treatment with Pifithrin- $\alpha$ reversed CK2-I-induced cell cycle arrest (Figure 4c). Similar results were obtained in U87 cells also (data not shown).

CK2-Is induces telomere shortening and senescence in a p53-dependent manner. Activation of p53 leads to telomere shortening, and repression of human telomerase reverse transcriptase (hTERT) activity by $p 53$ is mediated by p21. ${ }^{25}$ As p53 and p21 levels were elevated in CK2-I-treated p53 wild-type cells, we determined hTERT activity in cells treated with CK2-ls or TNF $\alpha$ or both. Although CK2-Is decreased hTERT activity, this decrease was greater in the presence of TNF $\alpha$. Importantly, CK2-I mediated reduction in hTERT activity was p53-dependent as the hTERT activity was reversed significantly in the presence of Pifithrin- $\alpha$ (Figure 5a).

As activation of p53-p21 pathway also acts as a major mediator of cellular senescence induced by CK2 inhibition, ${ }^{26}$ we determined $\beta$-galactosidase activity in CK2-I-treated glioma cells. The increase in senescence-positive cells observed in cells treated with CK2-I (Figure 5b) both in the presence and absence of TNF $\alpha$ (Figure $5 b$ ), was abrogated in the presence of Pifithrin- $\alpha$.

CK2-I-mediated abrogation of NF-кB and increase in p53 activation are independent events. Given that
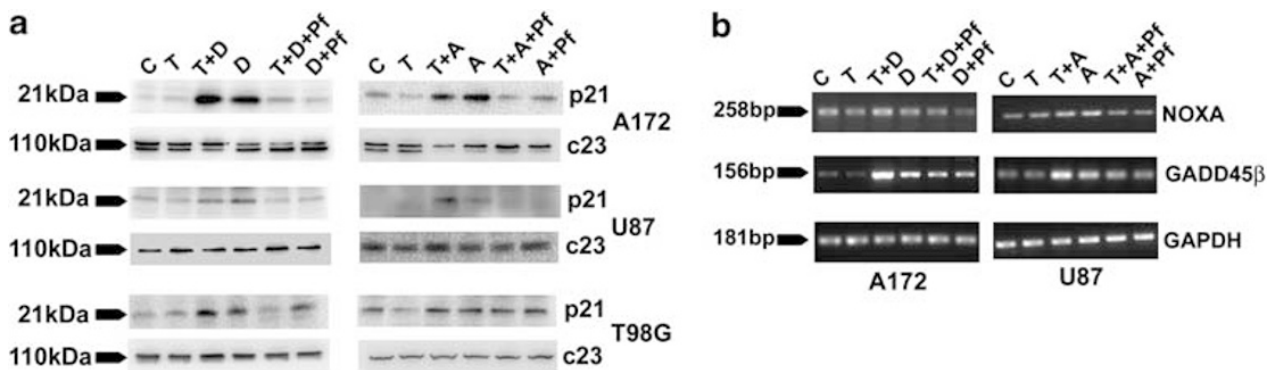

C
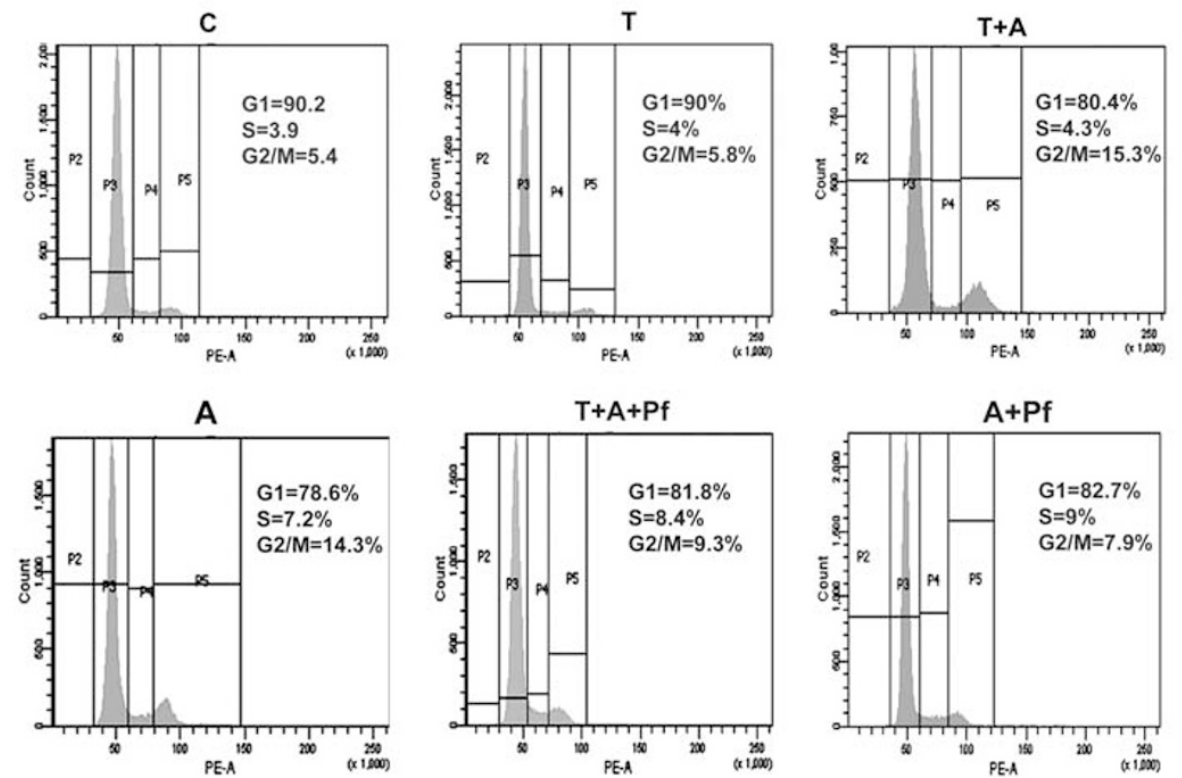

Figure 4 CK2 inhibitor affects p53 target genes associated with cell cycle regulation and apoptosis. (a) CK2-I increases p21 expression in a p53-dependent manner. Representative blot is shown from three independent experiments with identical results. Blots were re-probed with c23 to establish equivalent loading. (b) CK2-I increases mRNA levels of pro-apoptotic molecules Noxa and GADD $45 \beta$ in a p53-dependent manner. Total RNA was isolated from cells treated with different combinations of TNF $\alpha$ and CK2-I, and the mRNA levels for Noxa, GADD45 $\beta$ and constitutive enzyme GAPDH were determined by RT-PCR. (c) Pifithrin- $\alpha$ reverses CK2-I-mediated G2/M phase arrest in A172 cells. FACS analysis was performed on A172 cells treated with different combinations of TNF $\alpha$, CK2-Is and Pifithrin- $\alpha$. Inset indicates percentage of cells in G1, S and G2/M phase of the cell cycle. C, T, Pf and A denote control, TNF $\alpha$, Pifithrin- $\alpha$ and Apigenin, respectively 

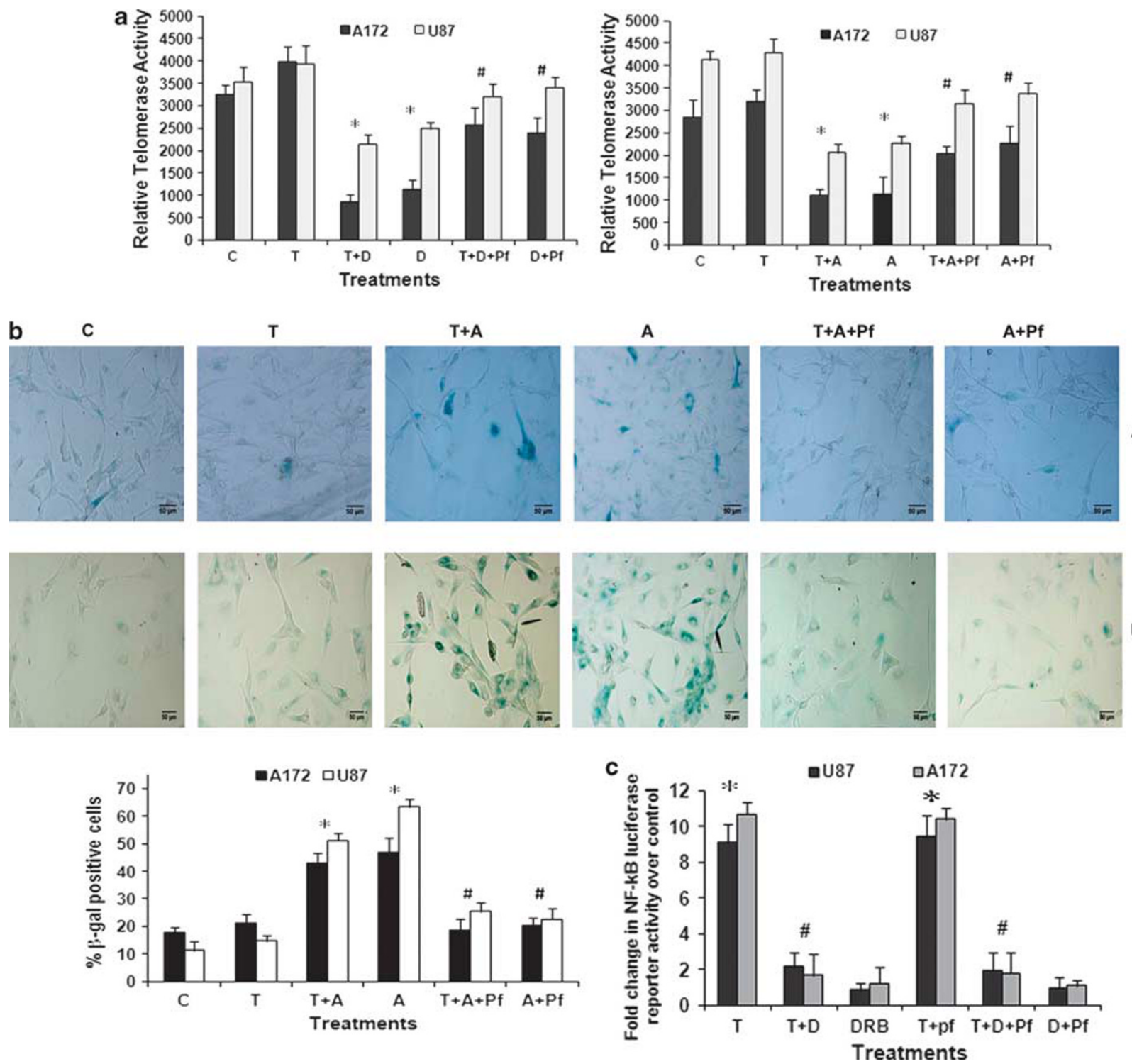

Figure 5 CK2 inhibition-induced p53 activation decreases telomerase activity and induces senescence but has no effect on NF- $\kappa$ B activity. (a) CK2-Is decrease telomerase activity in glioma cells in a p53-dependent manner. Glioma cells were treated with TNF $\alpha$ in the presence or absence of CK2-Is and/or Pifithrin- $\alpha$; and TeloTAGGG Telomerase PCR ELISA was performed. Values represent the means \pm S.E.M. from three independent experiments. (b) CK2-I-induced senescence in glioma cells is p53dependent as evident from senescence-specific $\beta$-gal staining. Images were taken at $20 \times$ magnification. The graph represents fold increase in $\beta$-gal-positive cells upon treatment with different combinations of Apigenin, TNF $\alpha$ and Pifithrin- $\alpha$. (c) Pifithrin- $\alpha$ does not affect the ability of DRB to abrogate TNF $\alpha$-induced NF- $\kappa B$ activation. The graph represents fold change in NF- $\kappa$ B luciferase activity over control, in cells treated with different combinations of TNF $\alpha$, DRB and Pifithrin- $\alpha$. Values in (a-c) represent the means \pm S.E.M. from three independent experiments. ${ }^{*}$ Denotes significant change from control $(P<0.05)$, ${ }^{\#}$ denotes significant change from CK2-I-treated cells $(P<0.05)$

TNF $\alpha$-activated NF- $\kappa$ B represses p53 transcriptional activity and vice versa, ${ }^{15}$ we investigated whether elevated p53 levels could have resulted in decreased NF- $\kappa \mathrm{B}$ activation in cells treated with a combination of $\mathrm{TNF} \alpha$ and CK2-Is. However, the ability of CK2-Is to downregulate TNF $\alpha$ induced $\mathrm{NF}-\kappa \mathrm{B}$ transcriptional activity was unaffected by Pifithrin- $\alpha$ (Figure $5 \mathrm{c}$ ). Thus, p53 activation and NF- $\kappa \mathrm{B}$ downregulation in CK2-I- and TNF $\alpha$-treated cells are two independent events.

CK2-Is differentially regulates expression of genes associated with apoptosis in TNF $\alpha$-treated p53 wild-type and mutant glioma cells. To further establish which apoptosis-related genes were altered upon treatment with CK2 inhibitor, we performed a quantitative real-time PCR (qRT-PCR)-based apoptotic gene array analysis. We observed distinct patterns of gene expression in cells treated with either TNF $\alpha$ or Apigenin or both in p53 wildtype (A172) and mutant (T98G) glioma cells. In p53 wild-type A172 glioma cells, among the 84 genes tested, transcript levels of 20 genes were increased upon $\mathrm{TNF} \alpha$ treatment and their increased levels were abrogated significantly with CK2-Is (Table 1a). Most of these anti-apoptotic genes are known to be regulated in $\mathrm{TNF} \alpha-$ and NF- $\kappa \mathrm{B}$-dependent 
Table 1 (a) A172 fold change over control; (b) T98G fold change over control

\begin{tabular}{|c|c|c|c|}
\hline & TNF $\mu$ & TNF+Api & Apigenin \\
\hline \multicolumn{4}{|l|}{ (a) } \\
\hline TNFRSF9 & 33.2205 & 2.5758 & -1.6189 \\
\hline TNFSF10 & 16.9592 & -4.6428 & -5.8159 \\
\hline BIRC3 & 23.007 & 7.9723 & 1.5746 \\
\hline CD40 & 14.1625 & 6.8924 & 2.6945 \\
\hline TNFRSF11B & 4.9383 & -5.6178 & -6.8448 \\
\hline RIPK2 & 2.0907 & -1.7839 & -3.0001 \\
\hline BCL2L11 & 1.9507 & -3.3058 & -3.5186 \\
\hline BIK & 3.2021 & 1.7171 & 1.366 \\
\hline XIAP & 1.3186 & -1.7777 & -2.3376 \\
\hline BNIP3 & 1.5147 & -1.7593 & -1.8987 \\
\hline NOD1 & 1.9372 & 1.1447 & -1.0755 \\
\hline CARD8 & 1.433 & -1.834 & -2.7132 \\
\hline TNFRSF1A & 1.428 & -4.3169 & -3.4702 \\
\hline CD70 & 1.8519 & -1.6702 & -2.8779 \\
\hline TRADD & 1.6748 & -2.4284 & -3.5925 \\
\hline TRAF2 & 2.7397 & 1.3996 & -1.5746 \\
\hline TRAF3 & 1.9106 & 1.3472 & -1.257 \\
\hline BCL2 & 1.4835 & -1.3472 & -3.1821 \\
\hline BCLAF1 & 1.458 & -2.0491 & -1.9319 \\
\hline BCL2L1 & 1.1321 & 10.7034 & 4.976 \\
\hline BCL2L10 & 1.8013 & 14.4701 & 11.2356 \\
\hline PYCARD & 1.9711 & 10.2319 & 5.3517 \\
\hline APAF1 & 1.1559 & 6.8211 & 5.5022 \\
\hline GADD45A & 2.1947 & 12.3805 & 8.6939 \\
\hline CIDEA & 3.093 & 10.8528 & 6.0002 \\
\hline TNFRSF10A & 3.1799 & 14.1232 & 10.2674 \\
\hline CASP10 & 1.7459 & 6.9886 & 5.5597 \\
\hline CASP14 & 3.4319 & 15.455 & 10.6664 \\
\hline CASP5 & 1.7279 & 5.2964 & 5.5597 \\
\hline BIRC6 & 1.1761 & -6.2333 & -4.8736 \\
\hline CRADD & 1.2008 & -3.1167 & -3.2603 \\
\hline CARD6 & 1.1966 & -4.7076 & -5.716 \\
\hline BAG4 & 1.1088 & -2.0139 & -2.6117 \\
\hline DAPK1 & -1.17 & -2.6299 & -2.7321 \\
\hline TP53 & 2.157 & -1.25 & -1.48 \\
\hline
\end{tabular}

(b)

$\begin{array}{lrcc}\text { BIRC3 } & 22.28 & 3.2 & 1.04 \\ \text { TNFRSF9 } & 33.54 & 3.71 & 1.1 \\ \text { RIPK2 } & 6.91 & 2.2 & 1.52 \\ \text { BCL2A1 } & 2.88 & 1.36 & 1.16 \\ \text { PYCARD } & 2.08 & -1.26 & -1.65 \\ \text { CFLAR } & 2.05 & -1.85 & -1.3 \\ \text { TRADD } & 1.88 & -2.33 & -1.49 \\ \text { TRAF2 } & 1.85 & -1.29 & 1.46 \\ \text { TRAF3 } & 2.41 & 1.39 & 1.45 \\ \text { CARD6 } & 1.62 & -1.65 & -1.15 \\ \text { XIAP } & 1.39 & -1.75 & -1.19 \\ \text { BIRC6 } & 1.21 & -2.01 & -1.22 \\ \text { NOL3 } & 1.06 & -3.68 & -1.15 \\ \text { TRAF4 } & 1.16 & -2.07 & -1.58 \\ \text { CASP10 } & 2.36 & 7.36 & 4.77 \\ \text { CASP14 } & -1.16 & 13.93 & 14.87 \\ \text { CASP5 } & -1.67 & 5.43 & 9.67 \\ \text { CIDEA } & 1.3 & 2.66 & 6.34 \\ \text { TP53 } & 1.2 & 1.01 & 1.25\end{array}$

Abbreviation: TNF, tumor necrosis factor. Quantitative real-time PCR to evaluate the relative transcript levels of a panel of 84 genes associated with apoptosis in cells treated with different combinations of CK2 inhibitor and TNF $\alpha$. Gene expression profiling of mRNA isolated from glioma cells - A172 (Table 1a) and T98G (Table 1b), treated with TNF $\alpha$ in the presence and absence of Apigenin, was analyzed by quantitative PCR for genes involved in apoptotic pathways. Expressions of several genes affected by the treatments are shown. Table represents the average data from two independent experiments

manner (TNFRSF9, TNFSF10, BIRC3, CD40, TNFRSF11B, RIPK2, BCL2L11, BID, BIK, XIAP, BNIP3, NOD1, CARD8, TNFRSF1A, CD70, TRADD, TRAF2, TRAF3, BCL2 and $B C L A F 1)$. Moreover, 10 genes (BCL2L1, BCL2L10,
PYCARD, APAF1, GADD45A, CIDEA, TNFRSF10A, CASP10, CASP14 and CASP5) were found to be upregulated by CK2-I independent of TNF $\alpha$ (Table 1a). Several of these genes were found to be p53-dependent proapoptotic factors. This indicated the importance of CK2-Iinduced p53 in regulating the pro-apoptotic response.

On the other hand, in p53 mutant T98G cell lines, transcript levels of $10 \mathrm{TNF} \alpha$ and $\mathrm{NF}-\kappa \mathrm{B}$ target genes (BIRC3, TNFRSF9, RIPK2, BCL2A1, PYCARD, CFLAR, TRADD, TRAF2, TRAF3 and CARD6) were increased upon TNF $\alpha$ treatment and their increased levels were brought down significantly by CK2-I. Moreover, levels of four pro-apoptotic genes (CASP10, CASP14, CASP5 and CIDEA) were upregulated upon $\mathrm{CK} 2$ inhibition. Similarly, transcript levels of four genes (XIAP, BIRC6, NOL3 and TRAF4) were downregulated significantly upon CK2-I treatment either alone or in presence of TNF $\alpha$. All of them are known apoptotic inhibitors (Table 1b).

CK2-I increases the stability of p53 by decreasing its ubiquitination. As CK2-I induced p53 expression without effecting its transcript level (Table 1), we investigated whether CK2-I-mediated increase in p53 level was the consequence of increased stability of the p53 protein. The role of CK2 on p53 stability was determined by treating glioma cells with protein synthesis inhibitor, Cycloheximide $(\mathrm{CHX})$, in the presence and absence of CK2-I. Although expression of p53 decreased rapidly after incubation with $\mathrm{CHX}$ in untreated cells, treatment with Apigenin prevented such degradation (Figure 6a). This suggested increased stabilization of p53 upon CK2 inhibition.

Decreased MDM2-p53 association upon CK2 inhibition leads to p53 stabilization. Ubiquitin ligase MDM2 negatively regulates p53 stability by promoting its ubiquitinmediated degradation ${ }^{27}$ and CK2 is known to regulate p53 turnover through MDM2. ${ }^{28}$ We therefore investigated whether CK2-mediated stabilization of p53 is MDM2dependent. As no change in MDM2 levels was observed upon treatment of glioma cells with CK2-I, both in the presence and absence of TNF $\alpha$ (data not shown), we investigated whether CK2-Is alter the association of p53 with MDM2. Association of p53 with MDM2 decreased upon CK2-I treatment (Figure 6b). It is possible that decreased MDM2-p53 association prevents rapid degradation of p53, leading to its accumulation in CK2-I-treated glioma cells. This decreased MDM2-p53 interaction was concomitant with decrease in p53 ubiquitination, suggesting that CK2-I increases p53 levels by preventing ubiquitin-mediated p53 degradation (Figure 6b).

CK2 regulates SIRT1 activity in glioma cells. As CK2 regulate $\mathrm{p} 53$ activity through SIRT1-dependent deacetylation ${ }^{18}$ and as we have observed increased p53 acetylation upon CK2-I treatment, we determined SIRT1 activity in cells treated with CK2-Is both in the presence and absence of TNF $\alpha$. A $\sim 30-40 \%$ decrease in SIRT1 activity was observed in CK2-I-treated cells independent of TNF $\alpha$ (Figure 7a). 
a

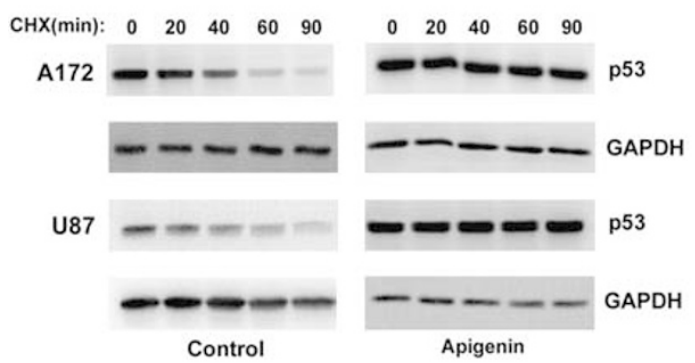

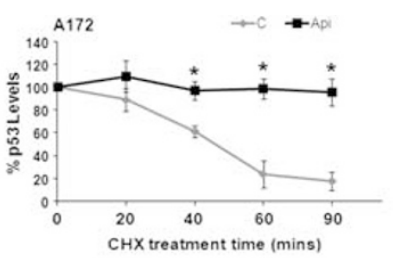

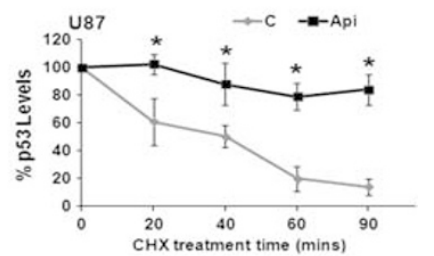

b

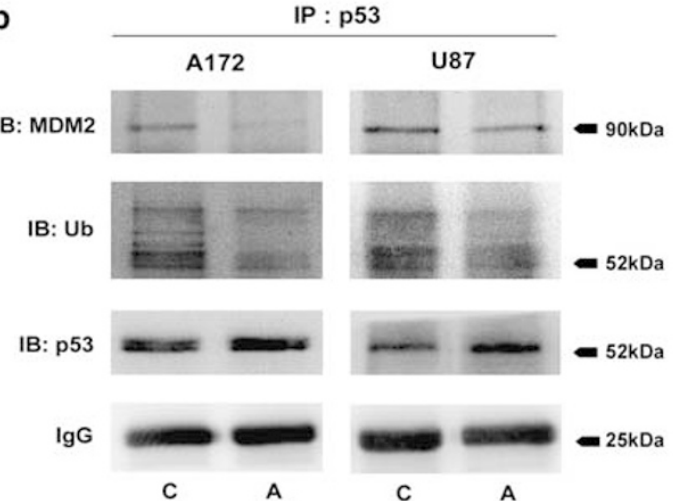

Figure 6 CK2 inhibition leads to p53 protein stabilization. (a) CK2-I prevents degradation of p53. Glioma cells, either untreated or treated with Apigenin for $12 \mathrm{~h}$ were further treated with $\mathrm{CHX}$ for the indicated times. Western blot analysis was performed to determine p53 levels in the lysates. Representative blot is shown from three independent experiments with identical results. Blots were reprobed for GAPDH to establish equivalent loading. Densitometric analysis shows p53 levels upon $\mathrm{CHX}$ treatment in the presence and absence of Apigenin. (b) CK2-I decreases MDM2-p53 interaction and p53 ubiquitination in glioma cells. Lysates from cells treated with Apigenin were immunoprecipitated with p53 and probed with antibodies against MDM2 and ubiquitin. IgG levels are shown to establish equivalent loading. Representative blot is shown from two independent experiments with identical results. *Denotes significant change from control $(P<0.05)$

Elevated SIRT1 levels in glioma samples. As SIRT1 is associated with tumorigenesis and resistant to radio- and chemotherapy, ${ }^{29}$ we determined its expression levels in GBM tumor samples as compared with adjacent normal tissue. We report for the first time an elevated expression of SIRT1 in GBM tumor samples as compared with the surrounding non-neoplastic tissue, as demonstrated by IHC and western blotting (Figure 7b).

Role of SIRT1 in CK2-I-induced p53-dependent glioma cell apoptosis. In order to confirm the involvement of CK2I-induced decrease in SIRT1 activity on glioma cell proliferation, we determined viability of cells over-expressing WT-SIRT1 in the presence and absence of CK2-ls. Over-expression of SIRT1 significantly prevented CK2-I-induced apoptosis both in the presence and absence of TNF $\alpha$ (Figure 7c).

As SIRT1 regulates $\mathrm{p} 53,{ }^{18}$ we next investigated the role of SIRT1 in CK2-I-induced p53 transcription activity in cells transfected with WT-SIRT1 in the presence and absence of CK2-Is and TNF $\alpha$. Increase in p53 transcriptional activity observed upon treatment with CK2-I was abrogated upon SIRT1 over-expression (Figure 7d). These results clearly suggested the involvement of SIRT1 in the regulation of CK2-I-induced p53 activation and subsequent decrease in glioma cells viability.

\section{Discussion}

Casein kinase-2 is reported to have a role in overcoming resistance of glioma cells towards radiation therapy. ${ }^{30}$ Moreover, CK2-Is target NF- $\kappa$ B signaling ${ }^{11}$ and as inactivation of NF- $\kappa$ B sensitizes glioma cells to TNF $\alpha$-induced apoptotic cell death. ${ }^{2,3}$ These findings compelled us to investigate whether inhibition of CK2 could sensitize glioma cells to TNF $\alpha$-induced apoptosis. We report for the first time an elevated expression of CK2 in GBM tumors as compared with the surrounding nonneoplastic tissue. Our studies indicate that CK2-Is DRB and Apigenin as well as CK2 siRNA sensitizes glioma cells to TNF $\alpha$-induced cell death. Though CK2 inhibitor trigger apoptosis through FADD and caspase-8, ${ }^{22}$ neither DRB nor Apigenin increased Fas or FADD expression or utilized caspase-8-mediated signaling to induce glioma cell death. CK2 is known to regulate TNF $\alpha$-dependent NF- $\kappa$ B activity, ${ }^{31}$ and similarly in glioma cells, treatment with both DRB and Apigenin abrogated TNF $\alpha$-induced NF- $\kappa \mathrm{B}$ activation.

CK2 inhibition in glioma cells triggered activity of wild-type p53 as evidenced by increased p53 levels, its phosphorylation and acetylation, DNA-binding ability and transcriptional activation. However, CK2-I failed to affect the functionality of mutant p53. It is known that receptor-interacting protein 1, which is a critical component of NF- $\kappa$ B signaling, inhibits p53 


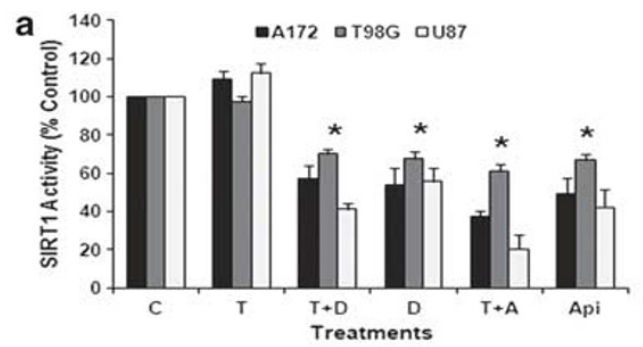

b
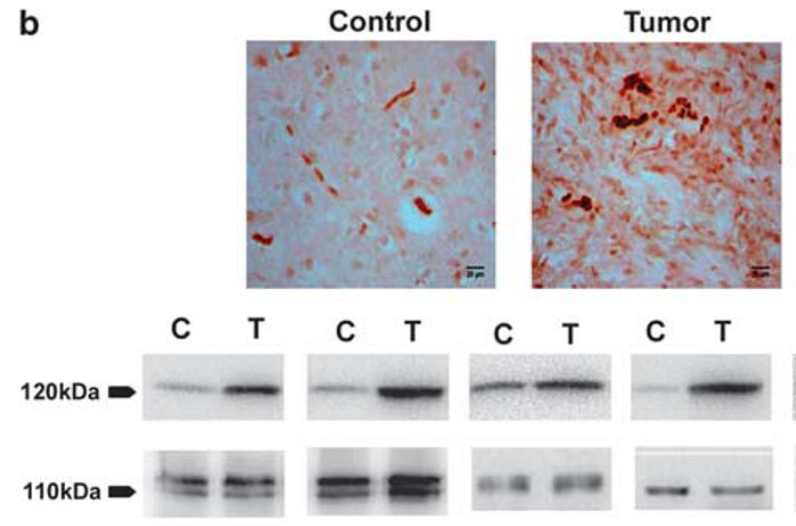

C T
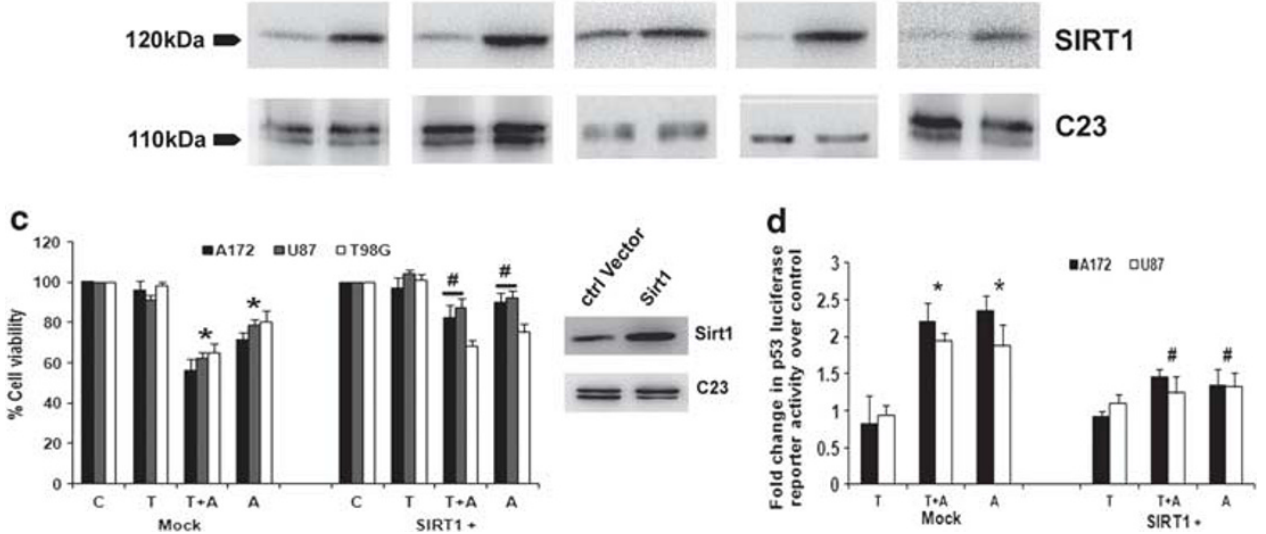

Figure 7 CK2 inhibitor-mediated downregulation of SIRT1 activity regulates p53. (a) CK2-Is decrease SIRT1 activity in glioma cells both in the presence and absence of $\mathrm{TNF} \alpha$. Glioma cells were treated with TNF $\alpha$ in the presence or absence of DRB/Api and subsequently SIRT1 activity was determined. Values represent the means \pm S.E.M. from three independent experiments. (b) SIRT1 immuno-localization in glioma tumor samples as revealed by IHC and western blot analysis. Cryosections of glioma and adjacent normal tissues were immunostained for SIRT1 as described in Materials and Methods. Images were taken at $40 \times$ magnification. Western blot analysis also demonstrated elevated SIRT1 levels in GBM tumor as compared with surrounding non-neoplastic tissue. The figure shows blots from five independent tumor samples with identical results. (c) CK2-I-mediated decrease in SIRT1 activity regulates glioma cell viability. The viability of glioma cells transfected with SIRT1 over-expression vector and treated with Apigenin or TNF $\alpha$ or both for $24 \mathrm{~h}$, was determined by MTS assay. The graph represents percentage viable cells of control. Inset shows the overexpressed SIRT1 levels as determined by immunoblotting. (d) CK2-I-mediated increase in p53 transcriptional activity is abrogated upon SIRT1 over-expression. Glioma cells co-transfected with SIRT1 over-expression vector and p53 luciferase reporter constructs were treated with Apigenin or TNF $\alpha$ or both and reporter assay was performed to determine p53 transcriptional activity. The graph represents fold change in $p 53$ luciferase reporter activity over control. Values in $(\mathbf{a}, \mathbf{c}$ and $\mathbf{d})$ represent the means \pm S.E.M. from three independent experiments. *Denotes significant change from control $(P<0.05)$, "denotes significant decrease from mock-transfected CK2-I-treated cells $(P<0.05)$

function through NF- $\kappa$ B activation in glioblastoma. ${ }^{32}$ It is possible that although CK2-I-induced p53 activation triggered cell death, it was the ability of CK2-Is to inhibit TNF $\alpha$-induced $\mathrm{NF}-\kappa \mathrm{B}$ activation that lead to synergistically enhanced cell death in the presence of TNF $\alpha$. Restoration of p53 function by CK2-Is was accompanied by elevated expression of p53 target genes p21, NOXA and GADD45 $\beta$ that are associated with apoptosis and cell cycle arrest. The results of gene expression profiling suggested differential responsiveness of p53 wild-type and mutant cells to CK2 inhibition, in terms of the expression of genes that are known p53 targets, as well as those relevant for the activation of caspases and induction of $\mathrm{TNF} \alpha$-mediated apoptosis. Gene profiling array also confirmed our observation that CK2 inhibition does not involve caspase- 8 , as no change in its levels was observed in cells treated with TNF $\alpha$ in the presence of Apigenin. Though CK2-I had no effect on the expression of p53 mRNA levels as demonstrated by the PCR array, it increased the stability of p53 protein by decreasing its ubiquitination and interaction with MDM2 to prevent subsequent degradation.

The decrease in SIRT-1 activity in glioma cells upon CK2 inhibition was associated with p53 activation, as overexpression of SIRT1 prevented CK2-I-mediated increase in p53 transcriptional activation. This was not surprising as CK2 regulates p53 activity directly and indirectly through SIRT-1. ${ }^{19}$ Importantly, SIRT1 over-expression rescued glioma cells from CK2-I-induced apoptosis. An increase in senescence was also observed in CK2-I-treated cells. It is possible that decrease in SIRT1 activity lead to senescence, as induction of senescence-like growth arrest in human breast and lung cancer cells by Sirtinol-a specific inhibitor for SIRT1 has been reported. ${ }^{33}$ Given that both CK2 and SIRT1 are elevated in 
GBM and their downregulation is concomitant with apoptosis and senescence, our study suggests that targeting CK2SIRT1 nexus might shed light on how CK2 regulates glioma progression.

Our studies indicate that CK2 inhibitor (i) sensitizes glioma cells to TNF $\alpha$-induced apoptosis in an caspase-8-independent manner (ii) decreases TNF $\alpha$-induced NF- $\kappa \mathrm{B}$ activation (iii) reactivates wild-type p53 function (iv) inhibits SIRT1 activity (v) inhibits telomerase activity and (vi) induces senescence (Figure 8). Taken together, CK2-I sensitizes both p53 wild-type and mutant glioma cells to TNF $\alpha$-induced apoptosis. Depending on the p53 status, this is achieved by CK2-Is either through abrogation of NF- $\kappa \mathrm{B}$ activation and/or rescue of wild-type p53 function. Importantly, this ability of CK2-I to induce glioma cell death irrespective of p53 status may be of clinical significance for the treatment of glioma, where p53 mutation is considered critical for its progression. ${ }^{16}$ Although activation of p53 triggers apoptosis, stimulation of $\mathrm{NF}-\kappa \mathrm{B}$ promotes resistance to apoptosis. Interestingly, CK2Is co-ordinate these two opposing events to overcome TNF $\alpha$ induced resistance to apoptosis. As induction of both senescence and apoptosis in human cancer cells has been reported, ${ }^{34}$ the ability of CK2-I to induce both these events to reduce cell viability warrants further investigation of CK2 as a potential anti-glioma target.

\section{Materials and Methods}

Processing of tissue and IHC. IHC was performed on tissue samples collected from patients with histologically confirmed GBM $(n=19)$ to determine CK2 and SIRT1 expression as described. ${ }^{35}$ Non-neoplastic brain tissue $(n=7)$ obtained from margins of the tumors whenever possible was used as control. Samples were obtained as per the guidelines of Institutional Human Ethics Committee of NBRC.

Cell culture and treatment. Glioblastoma cell lines A172, U87MG and T98G were obtained from American Type Culture Collection (ATCC, Manassas, VA, USA) and cultured in DMEM supplemented with $10 \%$ fetal bovine serum. On attaining semiconfluence, cells were switched to serum-free media (SFM) and after $12 \mathrm{~h}$, cells were

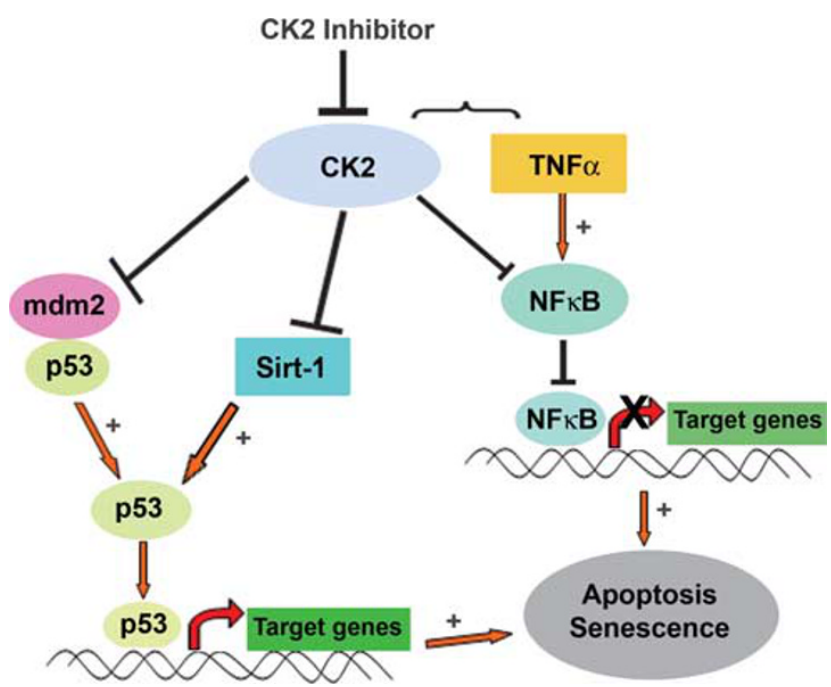

Figure 8 Proposed model demonstrating the role of CK2 in glioma cell apoptosis and resistance to therapy. CK2 inhibition induces glioma cell death via activation of p53 through SIRT1 inhibition and sensitizes glioma cell to TNF $\alpha$ via downregulation of TNF $\alpha$-induced NF- $\kappa B$ activity treated with different concentration of DRB or Apigenin (in Dimethyl sulphoxide, DMSO) or Pifithrin- $\alpha$ in the presence or absence of TNF $\alpha(50 \mathrm{ng} / \mathrm{ml})$ in SFM for $24 \mathrm{~h}$. DMSO-treated cells were used as controls. All reagents were purchased from Sigma unless otherwise stated. The p53 null cell lines $\mathrm{H} 1229$ and SaOS2 were a kind gift from Dr. Sanjeev Das, National institute of Immunology, India.

Determination of cell viability. Viability of cells treated with different combinations of TNF $\alpha$, CK2-Is and Pifithrin- $\alpha$ for $24 \mathrm{~h}$ in 96-well plates was assessed using the MTS assay (Promega, Madison, WI, USA) as described. ${ }^{36}$ Values were expressed as a percentage relative to those obtained in controls.

Western blot and immunoprecipitation. Protein was isolated from whole-cell lysates and nuclear extracts from cells treated with different combinations of TNF $\alpha$, CK2-Is and Pifithrin- $\alpha$ and western blot was performed as described ${ }^{37}$ The following antibodies were used: p21 (BD Biosciences, San Diego, CA, USA), pp53 ser15, MDM2, SIRT1 (Abcam, Cambridge, UK), acetylated p53 lys373, lys382 (Millipore, Temecula, CA, USA), plKK $\alpha / \beta$ (Ser176/180), I $\kappa \mathrm{B} \alpha, \mathrm{p} 53$ (Cell Signaling, Danvers, MA, USA), Ub (Dako, Glostrup, Denmark) CK2 $\alpha$, Fas and FADD, p53, p65, c23, GAPDH. Antibodies were purchased from Santa Cruz Biotechnology (Santa Cruz, CA, USA) unless otherwise mentioned. Secondary antibodies were purchased from Vector Laboratories Inc. (Burlingame, CA, USA). The blots were stripped and re-probed with anti- $\beta$-actin (Sigma, St. Louis, MO, USA) to determine equivalent loading as described. ${ }^{37}$ Immunoprecipitation was performed with p53 antibody to determine the association of p53-MDM2 as described. ${ }^{38}$

Assay of caspase-3 and 8 activities. The Colorimetric Assay kits for caspases-3 and 8 (Sigma) were used to determine the enzymatic activity of caspases in cells treated with different combinations of TNF $\alpha$ and CK2-ls as described. ${ }^{39}$

Luciferase reporter gene assay. Reporter assay in cells transfected with p53 or NF- $\kappa$ B luciferase or WT SIRT1 constructs, and treated with different combinations of TNF $\alpha$, CK2-Is and Pifithrin- $\alpha$ was performed as described. ${ }^{37}$ The p53 luciferase and SIRT1 constructs were obtained from Addgene (Cambridge, MA, USA) and NF- $\kappa$ B luciferase construct obtained from Clontech (Madison, WI, USA).

SiRNA transfection. Before $18 \mathrm{~h}$ of transfection, $3 \times 10^{4}$ cells were seeded onto 24-well plates in medium without antibiotics and transfection with $50 \mathrm{nmol} / /$ duplex CK2 $\alpha$, CK2 $\beta$, p53 or non-specific siRNA (Thermo Fischer Scientific, Lafayette, CO, USA) was carried using Lipofectamine RNAi Max reagent (Life Technologies-Invitrogen, Carlsbad, CA, USA) as described. ${ }^{40}$

p53 DNA-binding assay. DNA-binding activity of $p 53$ was measured with the DuoSet IC (IntraCellular) Assay Development System (R\&D Systems, Minneapolis, MN, USA) according to manufacturer's instructions.

Telomerase activity. Telomerase activity of cells treated with TNF $\alpha$ in the presence and absence of CK2-Is and Pifithrin- $\alpha$ was determined using the TeloTAGGG Telomerase PCR ELISA Plus kit (Roche Diagnostics, Mannheim, Germany) as described. ${ }^{39}$

Flow cytometric analysis of DNA content. FACS analysis was performed to determine the effect of TNF $\alpha$ or Apigenin or both in the presence and absence of Pifithrin $\alpha$ on cell cycle progression of glioma cells, using Cell Quest program on FACS Calibur (Becton Dickinson, San Diego, CA, USA) as described. ${ }^{5}$ Results were analyzed using Cell Quest pro software (Becton Dickinson).

Senescence-associated $\beta$-gal staining. Cells treated with CK2-Is either alone or in presence of TNF $\alpha$ and/or Pifithrin were stained with the senescenceassociated $\beta$-galactosidase (SA- $\beta$-gal) staining solution (Sigma) as per the manufacturer's instructions. The numbers of blue-stained (SA- $\beta$-gal-positive) cells and total cells were counted microscopically and percentage of SA- $\beta$-gal-positive cells was calculated.

SIRT1 activity assay. Deacetylase activity of SIRT1 was measured with SIRT1 activity assay kit from Calbiochem (Merck KGaA, Darmstadt, Germany) according to manufacturer's instructions. 
RT-PCR and human apoptosis qRT-PCR array. RT-PCR analyses for NOXA and GADD $45 \beta$ expression in cells treated with different combinations of TNF $\alpha$ and CK2-Is was performed as described. ${ }^{37}$ PCR primers for NOXA and GADD $45 \beta$ are listed in Supplementary Table 2. qRT-PCR was performed using an apoptosis PCR Array containing 84 apoptosis-related genes (SuperArray Biosciences, Frederick, MD, USA) as per manufacturer's instruction. Briefly, total RNA samples from $T N F \alpha$ and Apigenin-treated $A 172$ and T98G glioma cells were isolated using RNeasy Mini Kit (Qiagen, Hilden, Germany). An equal amount of RNA $(2 \mu \mathrm{g})$ was used for reverse transcription using RT2 First Strand Kit (SuperArray Biosciences). PCR reactions were done using the RT2 profiler PCR array PAHS-012 (Human Apoptosis PCR Array) on the ABI 7500 using RT2 Realtime SYBR Green PCR master mix PA-012. The total volume of the PCR reaction was $25 \mu \mathrm{l}$. The thermocycler parameters were $95^{\circ} \mathrm{C}$ for $10 \mathrm{~min}$, followed by 40 cycles of $95^{\circ} \mathrm{C}$ for $15 \mathrm{~s}$ and $60^{\circ} \mathrm{C}$ for $1 \mathrm{~min}$. Five housekeeping genes were included on the array (B2M, HPRT1, RPL13A, GAPDH, and ACTB) to normalize the transcript levels. Results were analyzed as per user manual guidelines using integrated web-based software package for the PCR Array System (SuperArray Biosciences RT2 Profiler PCR Array Human Apoptosis PAHS-012-A-12).

Statistical analysis. All comparisons between groups were performed using two-tailed paired student's $t$-test. All $P$-values $<0.05$ were taken as significant.

\section{Conflict of Interest}

The authors declare no conflict of interest.

Acknowledgements. The work was supported by a research grant from the Department of Biotechnology (DBT, Government of India \#BT/PR/12924/Med/30/ 235/2009). DD is supported by a research fellowship from Council of Scientific and Industrial Research (CSIR, Government of India).

1. Tsujimoto M, Yip YK, Vilcek J. Tumor necrosis factor: specific binding and internalization in sensitive and resistant cells. Proc Natl Acad Sci USA 1985; 82: 7626-7630.

2. Beg AA, Baltimore D. An essential role for NF-kappaB in preventing TNF-alpha-induced cell death. Science 1996; 274: 782-784.

3. Wang CY, Mayo MW, Baldwin Jr AS. TNF- and cancer therapy-induced apoptosis: potentiation by inhibition of NF-kappaB. Science 1996; 274: 784-787.

4. Safrit JT, Bonavida B. Sensitivity of resistant human tumor cell lines to tumor necrosis factor and adriamycin used in combination: correlation between down-regulation of tumor necrosis factor-messenger RNA induction and overcoming resistance. Cancer Res 1992; 52: $6630-6637$.

5. Sharma V, Tewari R, Sk UH, Joseph C, Sen E. Ebselen sensitizes glioblastoma cells to Tumor Necrosis Factor (TNFalpha)-induced apoptosis through two distinct pathways involving NF-kappaB downregulation and Fas-mediated formation of death inducing signaling complex. Int $J$ cancer 2008; 123: 2204-2212.

6. Litchfield DW. Protein kinase CK2: structure, regulation and role in cellular decisions of life and death. Biochem j 2003; 369 (Pt 1): 1-15.

7. Munstermann U, Fritz G, Seitz G, Lu YP, Schneider HR, Issinger OG. Casein kinase II is elevated in solid human tumours and rapidly proliferating non-neoplastic tissue. Eur $J$ Biochem 1990; 189: 251-257.

8. Yamane K, Kinsella TJ. CK2 inhibits apoptosis and changes its cellular localization following ionizing radiation. Cancer Res 2005; 65: 4362-4367.

9. Ravi R, Bedi A. Sensitization of tumor cells to Apo2 ligand/TRAIL-induced apoptosis by inhibition of casein kinase II. Cancer Res 2002; 62: 4180-4185.

10. Izeradjene K, Douglas L, Delaney A, Houghton JA. Influence of casein kinase II in tumor necrosis factor-related apoptosis-inducing ligand-induced apoptosis in human rhabdomyosarcoma cells. Clin Cancer Res 2004; 10: 6650-6660.

11. Romieu-Mourez R, Landesman-Bollag E, Seldin DC, Traish AM, Mercurio F, Sonenshein GE. Roles of IKK kinases and protein kinase CK2 in activation of nuclear factor-kappaB in breast cancer. Cancer Res 2001; 61: 3810-3818.

12. Rieger J, Frank B, Weller M, Wick W. Mechanisms of resistance of human glioma cells to Apo2 ligand/TNF-related apoptosis-inducing ligand. Cell Physiol Biochem 2007; 20: 23-34.

13. Wang D, Westerheide SD, Hanson JL, Baldwin AS Jr. Tumor necrosis factor alphainduced phosphorylation of RelA/p65 on Ser529 is controlled by casein kinase II. J Biol Chem 2000; 275: 32592-32597.

14. Romieu-Mourez R, Landesman-Bollag E, Seldin DC, Sonenshein GE. Protein kinase CK2 promotes aberrant activation of nuclear factor-kappaB, transformed phenotype, and survival of breast cancer cells. Cancer Res 2002; 62: 6770-6778.

15. Webster GA, Perkins ND. Transcriptional cross talk between NF-kappaB and p53. Mol Cell Biol 1999; 19: 3485-3495.

16. Kato $\mathrm{H}$, Kato $\mathrm{S}$, Kumabe $\mathrm{T}$, Sonoda $\mathrm{Y}$, Yoshimoto $\mathrm{T}$, Kato $\mathrm{S}$ et al. Functional evaluation of p53 and PTEN gene mutations in gliomas. Clin Cancer Res 2000; 6: 3937-3943.

17. Weinmann L, Wischhusen J, Demma MJ, Naumann U, Roth P, Dasmahapatra B et al. A novel p53 rescue compound induces p53-dependent growth arrest and sensitises glioma cells to Apo2L/TRAIL-induced apoptosis. Cell Death Diff 2008; 15: 718-729.

18. Vaziri $\mathrm{H}$, Dessain SK, Ng Eaton $\mathrm{E}$, Imai SI, Frye RA, Pandita TK et al. hSIR2(SIRT1) functions as an NAD-dependent p53 deacetylase. Cell 2001; 107: 149-159.

19. Kang H, Jung JW, Kim MK, Chung JH. CK2 is the regulator of SIRT1 substrate-binding affinity, deacetylase activity and cellular response to DNA-damage. PLOS One 2009; 4: e6611.

20. Chang CJ, Hsu CC, Yung MC, Chen KY, Tzao C, Wu WF et al. Enhanced radiosensitivity and radiation-induced apoptosis in glioma CD133-positive cells by knockdown of SirT1 expression. Biochem Biophys Res Commun 2009; 380: 236-242.

21. Prudent R, Moucadel V, Nguyen CH, Barette C, Schmidt F, Florent JC et al. Antitumor activity of pyridocarbazole and benzopyridoindole derivatives that inhibit protein kinase CK2. Cancer Res 2010; 70: 9865-9874.

22. Llobet D, Eritja N, Encinas M, Llecha N, Yeramian A, Pallares J et al. CK2 controls TRAIL and Fas sensitivity by regulating FLIP levels in endometrial carcinoma cells. Oncogene 2008; 27: 2513-2524.

23. Yu M, Yeh J, Van Waes C. Protein kinase casein kinase 2 mediates inhibitor-kappaB kinase and aberrant nuclear factor-kappaB activation by serum factor(s) in head and neck squamous carcinoma cells. Cancer Res 2006; 66: 6722-6731.

24. Badie B, Goh CS, Klaver J, Herweijer H, Boothman DA. Combined radiation and p53 gene therapy of malignant glioma cells. Cancer Gene Ther 1999; 6: 155-162.

25. Shats I, Milyavsky M, Tang X, Stambolsky P, Erez N, Brosh R et al. p53-dependent downregulation of telomerase is mediated by p21waf1. J Biol Chem 2004; 279: 50976-50985.

26. Kang JY, Kim JJ, Jang SY, Bae YS. The p53-p21(Cip1/WAF1) pathway is necessary for cellular senescence induced by the inhibition of protein kinase CKII in human colon cancer cells. Mol Cell 2009; 28: 489-494.

27. Haupt $\mathrm{Y}$, Maya R, Kazaz A, Oren M. Mdm2 promotes the rapid degradation of p53. Nature 1997; 387: 296-299.

28. Allende-Vega N, Dias S, Milne D, Meek D. Phosphorylation of the acidic domain of Mdm2 by protein kinase CK2. Mol Cell Biochem 2005; 274: 85-90.

29. Saunders LR, Verdin E. Sirtuins: critical regulators at the crossroads between cancer and aging. Oncogene 2007; 26: 5489-5504.

30. Olsen BB, Issinger OG, Guerra B. Regulation of DNA-dependent protein kinase by protein kinase CK2 in human glioblastoma cells. Oncogene 2010; 29: 6016-6026.

31. Piazza FA, Ruzzene M, Gurrieri C, Montini B, Bonanni L, Chioetto G et al. Multiple myeloma cell survival relies on high activity of protein kinase CK2. Blood 2006; 108: 1698-1707.

32. Park S, Hatanpaa KJ, Xie Y, Mickey BE, Madden CJ, Raisanen JM et al. The receptor interacting protein 1 inhibits p53 induction through NF-kappaB activation and confers a worse prognosis in glioblastoma. Cancer Res 2009; 69: 2809-2816.

33. Ota $\mathrm{H}$, Tokunaga $\mathrm{E}$, Chang K, Hikasa M, lijima K, Eto M et al. Sirt1 inhibitor, Sirtinol, induces senescence-like growth arrest with attenuated Ras-MAPK signaling in human cancer cells. Oncogene 2006; 25: 176-185.

34. Chen CR, Wang W, Rogoff HA, Li X, Mang W, Li CJ. Dual induction of apoptosis and senescence in cancer cells by Chk2 activation: checkpoint activation as a strategy against cancer. Cancer Res 2005; 65: 6017-6021.

35. Tewari R, Choudhury SR, Ghosh S, Mehta VS, Sen E. Involvement of TNFalpha-induced TLR4-NF-kappaB and TLR4-HIF-1alpha feed-forward loops in the regulation of inflammatory responses in glioma. J Mol Med 2012; 90: 67-80.

36. Koul N, Sharma V, Dixit D, Ghosh S, Sen E. Bicyclic triterpenoid Iripallidal induces apoptosis and inhibits Akt/mTOR pathway in glioma cells. BMC cancer 2010; 10: 328

37. Sharma V, Dixit D, Koul N, Mehta VS, Sen E. Ras regulates interleukin-1beta-induced HIF-1alpha transcriptional activity in glioblastoma. J Mol Med 2011; 89: 123-136.

38. Tewari R, Sharma V, Koul N, Ghosh A, Joseph C, Hossain Sk U et al. Ebselen abrogates TNFalpha induced pro-inflammatory response in glioblastoma. Mol Oncol 2009; 3: 77-83.

39. Sharma V, Koul N, Joseph C, Dixit D, Ghosh S, Sen E. HDAC inhibitor Scriptaid induces glioma cell apoptosis through JNK activation and inhibits telomerase activity. J Cell Mol Med 2009; 14: 2151-2161.

40. Sharma V, Dixit D, Koul N, Mehta VS, Sen E. Ras regulates interleukin-1beta-induced HIF-1alpha transcriptional activity in glioblastoma. J Mol Med 2011; 89: 123-136.

(c)

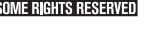

Cell Death and Disease is an open-access journal published by Nature Publishing Group. This work is licensed under the Creative Commons Attribution-Noncommercial-No Derivative Works 3.0 Unported License. To view a copy of this license, visit http://creativecommons.org/licenses/by-nc-nd/3.0/ 